\title{
Th17-related cytokines: new players in the control of chronic intestinal inflammation
}

\author{
Ivan Monteleone, Francesco Pallone and Giovanni Monteleone*
}

\begin{abstract}
Crohn's disease (CD) and ulcerative colitis (UC), the main forms of inflammatory bowel diseases (IBD) in man, are thought to be caused by an excessive and poorly controlled immune response that is directed against components of the normal microflora. The exact sequence of events by which this pathological process is triggered and maintained is not fully understood, but studies in experimental models of IBD and data emerging from recent clinical trials indicate that $\mathrm{T}$ cell-derived cytokines are crucial mediators of the tissue damage. Although CD and UC have been traditionally considered two typical examples of T helper (Th)1 or Th2-associated disease respectively, it is now known that CD- and UC-related inflammation is also marked by enhanced production of cytokines made by a distinct subset of Th cells, termed Th17 cells. Th17 cytokines can have both tissue-protective and inflammatory effects in the gut and there is evidence that Th17 cells can alter their cytokine program according to the stimuli received and convert into Th1-producing cells. These novel findings have contributed to advancing our understanding of mechanisms of gut tissue damage and open new avenues for development of therapeutic strategies in IBD.
\end{abstract}

\section{Background}

Crohn's disease (CD) and ulcerative colitis (UC), as the main inflammatory bowel diseases (IBD) in man, are chronic and relapsing inflammatory disorders $[1,2]$. The etiology of IBD is still unknown, but it is believed that genetic and environmental factors interact to promote an excessive and poorly controlled mucosal inflammatory response directed against components of the luminal microflora [1,2]. Studies in experimental models also

\footnotetext{
* Correspondence: Gi.Monteleone@Med.uniroma2.it

* Correspondence: Gi.Monteleone@Med.uniroma2.it
Dipartimento di Medicina Interna, Università Tor Vergata, Via Montpellier, 1, 00133 Rome, Italy
}

(c) 2011 Monteleone et al; licensee BioMed Central Ltd. This is an Open Access article distributed under the terms of the Creative indicate that IBD-related tissue damage results from a dynamic interplay between immune and non-immune cells and that cytokines are crucial mediators of this cross-talk [1,2]. Analysis of the cytokine profile in IBD tissue has however shown that CD and UC are immunologically distinct. In CD there is predominance of $\mathrm{T}$ helper (Th)1-related cytokines, such as IL-12 and interferon IFN- $\gamma$, while in UC there is more IL-5 and IL-13, two Th2-associated cytokines [3-6]. Nonetheless, the demonstration that both anti-IL-12/p40 and anti-IFN- $\gamma$ antibodies were only partially effective in patients with active $C D$ [7-9] suggests that $C D$ mucosal inflammation may be driven by additional mediators other than Th1 cytokines. Indeed, it is now well-known that CD and UC gut mucosa is heavily infiltrated with another subset of Th cells, termed Th17 cells, which produce a distinct array of cytokines [10-12]. In this article we review the available data supporting the role of Th17 cells in the modulation of gut inflammation and discuss whether and how Th17 cytokine-based therapy can enter into the therapeutic armamentarium of IBD.

\section{Th17-related cytokines are produced in excess in CD and} UC tissue

Th17 cells produce IL-17, also termed IL-17A, IL-17F, IL-21, IL-22, and IL-26 [13,14]. Th17 cells can also make IL-9 $[15,16]$. However, analysis at the single celllevel has revealed that not all Th17 cells secrete all these cytokines, probably reflecting the heterogeneity of this cell subset. In mice, transforming growth factor $\beta 1$ (TGF- $\beta 1$ ) and IL-6 induce naïve T cells to express the transcription factors retinoic acid-related orphan receptor (ROR) $\gamma$ t and ROR $\alpha$ and differentiate to Th17 cells $[17,18]$ (Figure 1). An optimal expansion and maintenance of Th17 cell response requires activation of the transcription factor Stat3 and IL-23 [19]. By contrast, it is not yet fully understood how human Th17 cells differentiate in vivo, even though in vitro studies indicate that activation of CD $4+$ cells in the presence of IL- $1 \beta$ and IL- 6 or IL-1 $\beta$ or IL-23 alone triggers IL-17A and IL-17F 


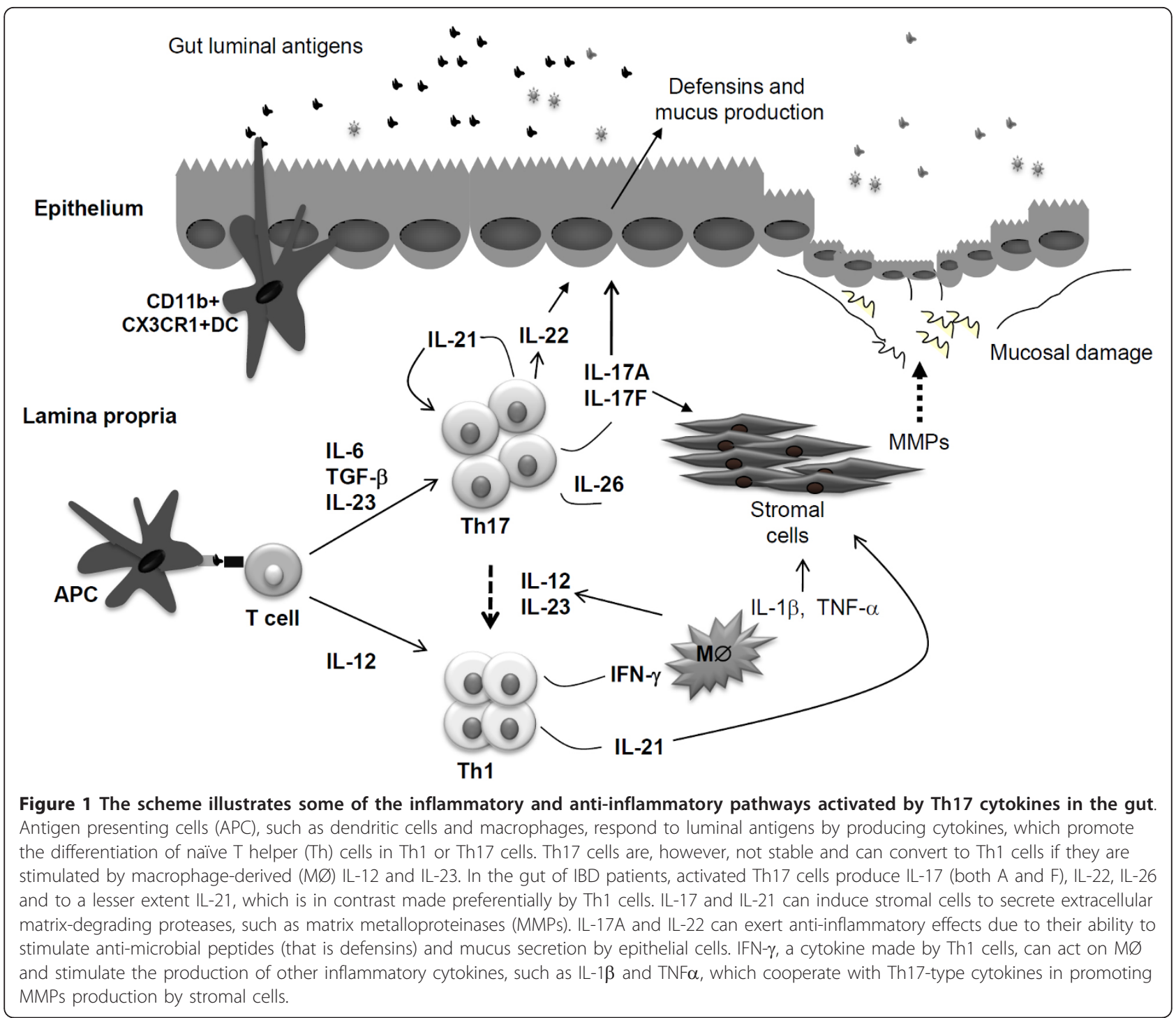

secretion $[20,21]$. IL-17A, IL-17F, IL-22 and IL-26 are all highly produced in the inflamed gut of patients with $C D$ and patients with UC [10,12,22-24]. Moreover, IBD genome-wide association studies and candidate gene studies showed that polymorphisms of Th17-related genes, such as Stat3 or $I L-23 R$, associate with IBD, thus supporting the involvement of the Th17 pathway into IBD pathogenesis [25-27]. Furthermore, elevated levels of CCL20, a chemoattractant for CCR6+ Th17 cells [28], have been documented in IBD mucosa, where CCL20 production seems to be positively regulated by IL-21, another Th17-related cytokine [29-31]. IL-21 is over-produced in the intestine of IBD patients, but the vast majority of IL21-producing CD4+ T cells co-express IFN- $\gamma$ and not IL-17A, thus suggesting that Th1 and not Th17 cells are major sources of IL-21 in the human gut [32,33] (Figure 1 ). This idea is supported by the fact that blockade of endogenous IL-12 in cultures of CD mucosal cells reduces IL-21 production while activation of normal intestinal CD4+ T lymphocytes in the presence of IL-12 increases the number of IL-21-secreting Th1 cells [32].

\section{The functional plasticity of Th17 cells}

Flow-cytometry analysis of mononuclear cells isolated from the gut of $C D$ patients has shown that some of the IL-17A-producing cells are not typical Th17 cells, because they co-express IFN- $\gamma$ [34]. The majority of IL$17 /$ IFN- $\gamma$-producing cells express CD161, a well known marker of NK T cells recently identified on IL-17-producing memory $\mathrm{T}$ cells [34]. These cells do not appear to be stable because in vitro stimulation with IL-12 enhances the expression of T-bet and IFN- $\gamma$, and downregulates ROR $\gamma$ t and IL-17A $[12,35]$. These findings support the notion that cells of the Th17 lineage are plastic 
and can be converted into Th1-type cells if they receive appropriate stimuli, such as IL-12 [12,35] (Figure 1). Although IL-23 was originally identified as a factor necessary for expanding/maintaining Th17 cell responses [19] and it is known that variants of the IL23R gene influence IL-22 secretion [36], recent studies have shown that IL-23 can also facilitate the deviation from a Th17 to a Th1 phenotype [37,38] (Figure 1). This is in line with the demonstration that some of the pathogenic effects of IL-23 in the gut are linked to the ability of this cytokine to turn on IFN- $\gamma$ [37]. Switching from IL-17A to IFN- $\gamma$ production occurs if Th17 cells are activated in a microenvironment devoid of TGF- $\beta 1$, because TGF- $\beta 1$ is needed to maintain IL-17A production by in vitro-generated Th17 cells $[21,39]$. Since in the gut of IBD patients, high Smad7 abrogates TGF- $\beta 1$ activity [40] and mucosal inflammation is marked by high IL-12 and IL-23 [3,41], it is conceivable that IFN- $\gamma$ producing cells seen in IBD tissue originate in part from pre-existing IL-17A-expressing T cells.

In addition to CD4+ $\mathrm{T}$ cells, many other cell types can produce Th17-related cytokines. For example, in IBD tissue, IL-17A is made by T cells and CD68+ macrophages [10]. NKT cells, NK cells, CD8 + T cells and $\gamma \delta$ $\mathrm{T}$ cells can also secrete IL-17A and IL-22 [34,42-44]. IL$17 \mathrm{~A}$ can also be produced by innate lymphoid cells (ILCs) $[45,46]$. IL-23-responsive ILCs, which are negative for CD3, CD127 and CD56, infiltrate the gut of patients with $\mathrm{CD}$ and the inflamed colons of Rag-deficient mice infected with Helicobacter Hepaticus [46,47]. These cells express high levels of IL-23R and ROR $\gamma$ t and produce IFN- $\gamma$, IL-17A and IL-22 in response to IL-23 [47]. Depletion of these cell types attenuates colitis in mice [47], thus emphasizing their pathogenic role in the gut.

\section{Th17 cytokines have both anti-inflammatory and inflammatory effects in the gut}

The discovery that Th17 cytokines are over-produced in IBD has boosted intensive research aimed at elucidating the contribution of each of these molecules in the control of gut inflammation. What has become evident is that some Th17 cytokines have both proinflammatory and tissue-protective properties, mostly depending on the model where they are studied. For example, there is evidence that IL-17A-knockout mice are more susceptible than control wild-type mice to developing colitis induced by oral administration of dextran sulfate sodium (DSS) [48]. DSS delivered with drinking water to mice causes disruption of the epithelial layer, which is followed by translocation of luminal bacteria to the mucosa and acute inflammatory response marked by a massive infiltration of the mucosa with neutrophils and macrophages [49]. Therefore, in this model, the tissue protective effect of IL-17A could rely on the ability of the cytokine to induce the expression of claudins in intestinal epithelial cells and to stimulate mucin production thereby enhancing the intestinal barrier [50] (Figure 1). An anti-inflammatory effect of IL-17A has also been seen in the T cell-transfer colitis model [51]. Indeed, it was shown that adoptive transfer of IL-17A-deficient naïve $\mathrm{CD} 4+\mathrm{T}$ cells to recipient immunodeficient mice results in severe colitis [51]. Transfer of IL-17 receptor (IL-17R)-deficient $\mathrm{T}$ cells to recipient mice induces the same aggressive disease, indicating that IL-17 exerts its protective effects directly on $\mathrm{T}$ cells [51]. The greater severity of colitis induced by transfer of IL-17A-deficient $\mathrm{T}$ cells is not due to their enhanced migratory and infiltration capacity, but is instead related to enhanced Th1 cell effector function, raising the possibility that the anti-inflammatory effect of IL-17A in this model relies on the inhibition of Th1 cell responses.

Like IL-17A knockout mice, mice lacking IL-22 develop severe colitis following oral DSS administration as compared to wild-type mice. This observation fits well with the demonstration that IL-22 enhances intestinal barrier integrity, a phenomenon which seems to be dependent on the ability of this cytokine to activate Stat3 [52]. IL-22 stimulates epithelial cell growth, goblet cell restitution and mucus and antimicrobial production, thus restricting the passage of luminal commensal flora and food antigens to the lamina propria [23,52] (Figure 1 ). IL-22-mediated protective effects are also seen in the $\mathrm{T}$ cell transfer colitis model [53].

In contrast, mice deficient in IL-17RA are largely protected against experimental colitis induced by intrarectal administration of trinitrobenzenesulfonic acid (TNBS), and administration of IL-17RA IgG1 fusion protein attenuates TNBS-colitis in wild-type mice [54]. The fact that IL-17RA mediates the functional activities of both IL-17A and IL-17F [55] together with the above protective effects of IL-17A suggest that IL-17F, and not IL$17 \mathrm{~A}$, is pathogenic in the gut. This idea is supported by the demonstration that mice deficient in IL-17F are largely resistant against DSS-colitis [48]. The mechanism by which IL-17F promotes gut inflammation is not yet known, but there is evidence that this cytokine can induce the synthesis of various molecules (that is, TNF, IL-1, IL- 6 and chemokines) that amplify pathogenic responses in the intestine [13,14].

Despite the above data suggesting that IL-17A has anti-inflammatory effects in the gut, we cannot exclude the possibility that, under specific circumstances, this cytokine can cooperate with IL-17F and other Th17 or Th1 cytokines to expand the IBD-associated inflammatory response. This hypothesis is supported by studies performed by Leppkes and colleagues [56] showing that transfer of IL-17A-, IL-17F-, or IL-22-deficient T 
lymphocytes into RAG1-null mice induces severe colitis that is indistinguishable from that caused by wild-type cells. In contrast, transfer of ROR $\gamma$-null $\mathrm{T}$ cells, which associates with no induction of IL-17 cytokines in the intestine, does not induce colitis [56]. Moreover, treatment of RAG1 mice that received IL-17F-null T cells with a neutralizing anti-IL-17A antibody suppresses disease [56].

Transfer of naïve CD8+ T cells into syngeneic RAGdeficient mice results in severe colitis, similar to that seen after transfer of naïve CD4+ T cells [57]. Analysis of CD8+ $\mathrm{T}$ cells in the mesenteric lymph nodes of such mice show the existence of IL-17A and IFN- $\gamma$ double-positive cells. Notably, transfer of naïve CD8+ $\mathrm{T}$ cells derived from either IL-17- or IFN- $\gamma$-knockout mice is associated with less severe colitis. Like naïve CD4+ cells lacking ROR $\gamma t, C D 4+T$ cells deficient in Th1-related transcription factors (that is, Stat 4 and Tbet) are unable to induce colitis when transferred to recipient mice $[58,59]$. Altogether these observations suggest that a mixture of both Th1 and Th17 cytokines are needed to promote pathology in the gut and that compounds interfering with both Th1 and Th17 cell activity could be useful to facilitate the resolution of the ongoing mucosal inflammation in IBD. In this context, a promising target could be IL-21, whose activity seems to be necessary for expanding both Th1 and Th17 cell responses in the gut $[32,60]$. Like human IBD, mice with acute DSS-colitis and TNBS-relapsing colitis produce elevated levels of IL-21, and administration of a neutralizing IL-21R fusion protein to DSStreated mice attenuates the ongoing colitis and reduces the production of Th17-related cytokines [60]. IL-21deficient mice are largely protected against DSS- and TNBS-colitis, and this protection is associated with a marked decrease in IL-17A and IL-17F, thus confirming the key role of IL-21 in sustaining Th17 immunity [60]. IL-21 exerts further biological functions that could contribute to its pro-inflammatory effect in the gut. For example, IL-21 inhibits the peripheral differentiation of regulatory $\mathrm{T}$ cells (Tregs) and makes CD4 $+\mathrm{T}$ cells resistant to Tregs-mediated immune suppression [61]. Like IL-17A, IL-21 stimulates stromal cells to produce tissue-degrading proteases [62] (Figure 1). Human intestinal epithelial cells express IL-21R and respond to IL-21 by up-regulating the secretion of the $\mathrm{T}$ cell chemoattractant macrophage inflammatory protein-3 $\alpha$ [31]. It remains unknown, however, if this occurs also in mice, because no study has yet demonstrated that murine colonic epithelial cells express IL21R. Finally, there is evidence that IL-21 enhances the expression of Th1-related transcription factors and IFN- $\gamma$ in T and NK cells $[63,64]$.

\section{Aryl hydrocarbon receptor signalling promotes IL-22 synthesis and attenuates gut inflammation}

Th17 cells that have lost the ability to secrete IL-17A and turned on IFN- $\gamma$ express high levels of aryl hydrocarbon receptor (AhR) $[65,66]$, raising the possibility that AhR can control the activity of these cells. AhR is a transcription factor ubiquitously expressed in vertebrate cells and able to mediate a range of cellular events in response to halogenated aromatic hydrocarbons, nonhalogenated polycyclic aromatic hydrocarbons, small synthetic compounds and natural chemicals, including derivatives of tryptophan, such as 6-formylindolo (3, 2b) carbazole (Ficz) [67]. Activation of AhR results in enhanced production of Th17 cytokines, particularly IL22, and reduction of Th1 and Th2 cytokine [65,68-72]. There is however evidence that AhR-deficient CD4+ T cells can be induced to differentiate along the Th17 pathway, thus suggesting that $A h R$ is probably involved in the expansion, rather than induction, of Th17 cells [73]. In line with the above findings, we have recently shown that administration of Ficz to mice ameliorated TNBS-, relapsing DSS- and T cell-transfer colitis [74]. These data were paralleled by inhibition of Th1 cytokines and up-regulation of IL-22. Moreover, treatment of mice with an AhR antagonist reduced IL-22 production and enhanced the severity of TNBS-colitis [74]. Blockade of IL-22 with a neutralizing antibody reversed the therapeutic effect of Ficz in mice with TNBS-colitis, thus indicating that induction of IL-22 is one of the major mechanisms by which AhR signals control pathogenic responses in the gut [74].

Analysis of AhR expression in human IBD demonstrated a marked down-regulation in the inflamed tissue of $C D$ patients as compared to uninvolved areas of the same patients, inflamed areas of UC patients and normal controls. Importantly, AhR content did not significantly differ between UC and normal control samples thus suggesting that the diminished expression of AhR in CD is not an epiphenomenon of the ongoing inflammation [74]. As in mice, treatment of human IBD mucosal cells with Ficz resulted in decreased IFN- $\gamma$ expression and up-regulation of IL-22. Time-course studies showed, however, that suppression of Th1 cell response preceded IL-22 induction thus supporting the ability of AhR to control distinct pathways of mucosal damage and healing [74].

\section{Summary and future directions}

The findings described in this article together with the beneficial effects of Th17-cytokine blockers in immunemediated pathologies, such as psoriasis [75], suggest that targeting Th17 cytokines could be a rationale approach to dampen the detrimental inflammatory response in 
IBD. However, results of clinical trials of two different antibodies neutralizing the IL-23/p40 subunit were quite disappointing in $C D[7,76]$ and a recent study has shown that blockade of IL-17A is not effective in CD [77]. These negative results are not, however, entirely surprising because, as pointed out in this article, the IBD-associated tissue-damaging immune response is driven by additional cytokines other than Th17-related molecules. If so, we can speculate that simultaneous neutralization of two or more of these molecules (for eample IFN- $\gamma$ and IL-17A) could help manage the active phases of IBD patients.

\section{Conclusions}

In recent years, progress in basic and translational research has led to a better understanding of the role of Th17 cytokines in the control of gut inflammation. What has become evident is that these molecules can have both inflammatory and anti-inflammatory effects in the gut and that some cytokines can cooperate with molecules produced by other cell subsets in amplifying inflammatory processes. The available data seem to suggest that compounds inhibiting some Th17-related cytokines (that is IL-17A, IL-22) could not be effective in IBD or could worsen the IBD course. By contrast, it is conceivable that blockers of IL-21 or IL-17F are more advantageous because these two cytokines sustain multiple inflammatory signals in the gut. However, given the clinical and biological heterogeneity of IBD, further experimentation will be necessary to establish whether IL-21 and IL-17F are produced at a high level during the various phases of the disease.

\begin{abstract}
Abbreviations
AhR: aryl hydrocarbon receptor; CD: Crohn's disease; DSS: dextran sulfate sodium; Ficz: 6-formylindolo (3: 2-b) carbazole; IBD: inflammatory bowel disease; IFN: interferon; IL: interleukin; ILC: innate lymphoid cells; IL-17R: interleukin-17 receptor; ROR: retinoic acid related orphan receptor; TGF: transforming growth factor; TNBS: trinitrobenzenesulfonic acid; Tregs: regulatory T cells; UC: ulcerative colitis.
\end{abstract}

\section{Authors' contributions}

IM, FP and GM have contributed equally to drafting the manuscript and making the figure. All authors read and approved the final manuscript.

\section{Competing interests}

G.M. has filed a patent entitled 'Interleukin-21 (IL-21) binding proteins and methods of making and using same' (European Patent Application No.08425294.9).

Received: 29 July 2011 Accepted: 15 November 2011

Published: 15 November 2011

\section{References}

1. Kaser A, Zeissig S, Blumberg RS: Inflammatory bowel disease. Annu Rev Immunol 2010, 28:573-621.

2. Strober W, Fuss I, Mannon P: The fundamental basis of inflammatory bowel disease. J Clin Invest 2007, 117:514-521.
3. Monteleone G, Biancone L, Marasco R, Morrone G, Marasco O, Luzza F, Pallone F: Interleukin 12 is expressed and actively released by Crohn's disease intestinal lamina propria mononuclear cells. Gastroenterology 1997, 112:1169-1178.

4. Fuss IJ, Neurath M, Boirivant M, Klein JS, de la Motte C, Strong SA, Fiocchi C, Strober W: Disparate CD4+ lamina propria (LP) lymphokine secretion profiles in inflammatory bowel disease. Crohn's disease LP cells manifest increased secretion of IFN-gamma, whereas ulcerative colitis LP cells manifest increased secretion of IL-5. J Immunol 1996, 157:1261-1270.

5. Fuss IJ, Heller F, Boirivant M, Leon F, Yoshida M, Fichtner-Feigl S, Yang Z, Exley M, Kitani A, Blumberg RS, Mannon P, Strober W: Nonclassical CD1drestricted NK T cells that produce IL-13 characterize an atypical Th2 response in ulcerative colitis. J Clin Invest 2004, 113:1490-1497.

6. Heller F, Florian P, Bojarski C, Richter J, Christ M, Hillenbrand B, Mankertz J, Gitter AH, Burgel N, Fromm M, Zeitz M, Fuss I, Strober W, Schulzke JD: Interleukin-13 is the key effector Th2 cytokine in ulcerative colitis that affects epithelial tight junctions, apoptosis, and cell restitution. Gastroenterology 2005, 129:550-564.

7. Sandborn WJ, Feagan BG, Fedorak RN, Scherl E, Fleisher MR, Katz S, Johanns J, Blank M, Rutgeerts P: A randomized trial of Ustekinumab, a human interleukin-12/23 monoclonal antibody, in patients with moderate-to-severe Crohn's disease. Gastroenterology 2008, 135:1130-1141.

8. Reinisch W, de Villiers W, Bene L, Simon L, Racz I, Katz S, Altorjay I, Feagan B, Riff D, Bernstein CN, Hommes D, Rutgeerts P, Cortot A, Gaspari M, Cheng M, Pearce T, Sands BE: Fontolizumab in moderate to severe Crohn's disease: a phase 2, randomized, double-blind, placebocontrolled, multiple-dose study. Inflamm Bowel Dis 2010, 16:233-242.

9. Hommes DW, Mikhajlova TL, Stoinov S, Stimac D, Vucelic B, Lonovics J, Zakuciova M, D'Haens G, Van Assche G, Ba S, Lee S, Pearce T: Fontolizumab, a humanised anti-interferon gamma antibody, demonstrates safety and clinical activity in patients with moderate to severe Crohn's disease. Gut 2006, 55:1131-1137.

10. Fujino S, Andoh A, Bamba S, Ogawa A, Hata K, Araki Y, Bamba T, Fujiyama $Y$ : Increased expression of interleukin 17 in inflammatory bowel disease. Gut 2003, 52:65-70.

11. Rovedatti L, Kudo T, Biancheri P, Sarra M, Knowles CH, Rampton DS, Corazza GR, Monteleone G, Di Sabatino A, Macdonald TT: Differential regulation of interleukin 17 and interferon gamma production in inflammatory bowel disease. Gut 2009, 58:1629-1636.

12. Annunziato F, Cosmi L, Santarlasci V, Maggi L, Liotta F, Mazzinghi B, Parente E, Fili L, Ferri S, Frosali F, Giudici F, Romagnani P, Parronchi P, Tonelli $F$, Maggi E, Romagnani S: Phenotypic and functional features of human Th17 cells. J Exp Med 2007, 204:1849-1861.

13. Bettelli $E$, Korn T, Oukka M, Kuchroo VK: Induction and effector functions of $\mathrm{T}(\mathrm{H}) 17$ cells. Nature 2008, 453:1051-1057.

14. Korn T, Bettelli E, Oukka M, Kuchroo VK: IL-17 and Th17 Cells. Annu Rev Immunol 2009, 27:485-517.

15. Stephens GL, Swerdlow B, Benjamin E, Coyle AJ, Humbles A, Kolbeck R, Fung M: IL-9 is a Th17-derived cytokine that limits pathogenic activity in organ-specific autoimmune disease. Eur J Immunol 2011, 41:952-962.

16. Beriou G, Bradshaw EM, Lozano E, Costantino CM, Hastings WD, Orban T, Elyaman W, Khoury SJ, Kuchroo VK, Baecher-Allan C, Hafler DA: TGF-beta induces IL-9 production from human Th17 cells. J Immunol 2010, 185:46-54.

17. Yang XO, Pappu BP, Nurieva R, Akimzhanov A, Kang HS, Chung $Y$, Ma L, Shah B, Panopoulos AD, Schluns KS, et al: T helper 17 lineage differentiation is programmed by orphan nuclear receptors ROR alpha and ROR gamma. Immunity 2008, 28:29-39.

18. Zhang F, Meng G, Strober W: Interactions among the transcription factors Runx1, RORgammat and Foxp3 regulate the differentiation of interleukin 17-producing T cells. Nat Immunol 2008, 9:1297-1306.

19. Zhou L, Spolski R, Min R, Shenderov K, Egawa T, Levy DE, Leonard WJ, Littman DR: IL-6 programs $\mathrm{T}(\mathrm{H})-17$ cell differentiation by promoting sequential engagement of the IL-21 and IL-23 pathways. Nat Immunol 2007, 8:967-974

20. Sutton C, Brereton C, Keogh B, Mills KH, Lavelle EC: A crucial role for interleukin (IL)-1 in the induction of IL-17-producing T cells that mediate autoimmune encephalomyelitis. J Exp Med 2006, 203:1685-1691.

21. Volpe E, Servant N, Zollinger R, Bogiatzi SI, Hupe P, Barillot E, Soumelis V: A critical function for transforming growth factor-beta, interleukin 23 and 
proinflammatory cytokines in driving and modulating human $\mathrm{T}(\mathrm{H})-17$ responses. Nat Immunol 2008, 9:650-657.

22. Seiderer J, Elben I, Diegelmann J, Glas J, Stallhofer J, Tillack C, Pfennig S, Jurgens M, Schmechel S, Konrad A, Göke B, Ochsenkühn T, MüllerMyhsok B, Lohse P, Brand S: Role of the novel Th17 cytokine IL-17F in inflammatory bowel disease (IBD): upregulated colonic IL-17F expression in active Crohn's disease and analysis of the IL17F p.His161Arg polymorphism in IBD. Inflamm Bowel Dis 2008, 14:437-445.

23. Brand S, Beigel F, Olszak T, Zitzmann K, Eichhorst ST, Otte JM, Diepolder H, Marquardt A, Jagla W, Popp A, Leclair S, Herrmann K, Seiderer J, Ochsenkühn T, Göke B, Auernhammer CJ, Dambacher J: IL-22 is increased in active Crohn's disease and promotes proinflammatory gene expression and intestinal epithelial cell migration. Am J Physiol Gastrointest Liver Physiol 2006, 290:G827-838.

24. Dambacher J, Beigel F, Zitzmann K, De Toni EN, Goke B, Diepolder HM, Auernhammer CJ, Brand S: The role of the novel Th17 cytokine IL-26 in intestinal inflammation. Gut 2009, 58:1207-1217.

25. Franke A, McGovern DP, Barrett JC, Wang K, Radford-Smith GL, Ahmad T, Lees CW, Balschun T, Lee J, Roberts R, Anderson CA, Bis JC, Bumpstead S, Ellinghaus D, Festen EM, Georges M, Green T, Haritunians T, Jostins L, Latiano A, Mathew CG, Montgomery GW, Prescott NJ, Raychaudhuri S, Rotter JI, Schumm P, Sharma Y, Simms LA, Taylor KD, Whiteman D, et al: Genome-wide meta-analysis increases to 71 the number of confirmed Crohn's disease susceptibility loci. Nat Genet 2010, 42:1118-1125.

26. Anderson CA, Boucher G, Lees CW, Franke A, D'Amato M, Taylor KD, Lee JC, Goyette P, Imielinski M, Latiano A, Lagacé C, Scott R, Amininejad L, Bumpstead S, Baidoo L, Baldassano RN, Barclay M, Bayless TM, Brand S, Büning C, Colombel JF, Denson LA, De Vos M, Dubinsky M, Edwards C, Ellinghaus D, Fehrmann RS, Floyd JA, Florin T, Franchimont D, et al: Metaanalysis identifies 29 additional ulcerative colitis risk loci, increasing the number of confirmed associations to 47. Nat Genet 2011, 43:246-252.

27. Glas J, Stallhofer J, Ripke S, Wetzke M, Pfennig S, Klein W, Epplen JT, Griga T, Schiemann U, Lacher M, Koletzko S, Folwaczny M, Lohse P, Göke B, Ochsenkühn T, Müller-Myhsok B, Brand S: Novel genetic risk markers for ulcerative colitis in the IL2/L21 region are in epistasis with IL23R and suggest a common genetic background for ulcerative colitis and celiac disease. Am J Gastroenterol 2009, 104:1737-1744.

28. Wang C, Kang SG, Lee J, Sun Z, Kim CH: The roles of CCR6 in migration of Th17 cells and regulation of effector T-cell balance in the gut. Mucosal Immunol 2009, 2:173-183.

29. Kaser A, Ludwiczek O, Holzmann S, Moschen AR, Weiss G, Enrich B, Graziadei I, Dunzendorfer S, Wiedermann CJ, Murzl E, Grasl E, Jasarevic Z, Romani N, Offner FA, Tilg H: Increased expression of CCL20 in human inflammatory bowel disease. J Clin Immunol 2004, 24:74-85.

30. Brand S, Olszak T, Beigel F, Diebold J, Otte JM, Eichhorst ST, Goke B, Dambacher J: Cell differentiation dependent expressed CCR6 mediates ERK-1/2, SAPK/JNK, and Akt signaling resulting in proliferation and migration of colorectal cancer cells. J Cell Biochem 2006, 97:709-723.

31. Caruso R, Fina D, Peluso I, Stolfi C, Fantini MC, Gioia V, Caprioli F, Del Vecchio Blanco G, Paoluzi OA, Macdonald TT, Pallone F, Monteleone G: A functional role for interleukin-21 in promoting the synthesis of the T-cell chemoattractant, MIP-3alpha, by gut epithelial cells. Gastroenterology 2007, 132:166-175.

32. Monteleone G, Monteleone I, Fina D, Vavassori P, Del Vecchio Blanco G Caruso R, Tersigni R, Alessandroni L, Biancone L, Naccari GC, MacDonald TT, Pallone F: Interleukin-21 enhances T-helper cell type I signaling and interferon-gamma production in Crohn's disease. Gastroenterology 2005, 128:687-694

33. Sarra M, Monteleone I, Stolfi C, Fantini MC, Sileri P, Sica G, Tersigni R, Macdonald TT, Pallone F, Monteleone G: Interferon-gamma-expressing cells are a major source of interleukin-21 in inflammatory bowel diseases. Inflamm Bowel Dis 2010, 16:1332-1339.

34. Kleinschek MA, Boniface K, Sadekova S, Grein J, Murphy EE, Turner SP, Raskin L, Desai B, Faubion WA, de Waal Malefyt R, Pierce RH, McClanahan T, Kastelein RA: Circulating and gut-resident human Th17 cells express CD161 and promote intestinal inflammation. J Exp Med 2009, 206:525-534.

35. Boniface K, Blumenschein WM, Brovont-Porth K, McGeachy MJ, Basham B, Desai B, Pierce R, McClanahan TK, Sadekova S, de Waal Malefyt R: Human Th17 cells comprise heterogeneous subsets including IFN-gamma- producing cells with distinct properties from the Th1 lineage. J Immunol 2010, 185:679-687.

36. Schmechel S, Konrad A, Diegelmann J, Glas J, Wetzke M, Paschos E, Lohse P, Goke B, Brand S: Linking genetic susceptibility to Crohn's disease with Th17 cell function: IL-22 serum levels are increased in Crohn's disease and correlate with disease activity and IL23R genotype status. Inflamm Bowel Dis 2008, 14:204-212.

37. Ahern PP, Schiering C, Buonocore S, McGeachy MJ, Cua DJ, Maloy KJ, Powrie F: Interleukin-23 drives intestinal inflammation through direct activity on T cells. Immunity 2010, 33:279-288.

38. Lee YK, Turner H, Maynard CL, Oliver JR, Chen D, Elson CO, Weaver CT: Late developmental plasticity in the T helper 17 lineage. Immunity 2009, 30:92-107.

39. Lee YK, Mukasa R, Hatton RD, Weaver CT: Developmental plasticity of Th17 and Treg cells. Curr Opin Immunol 2009, 21:274-280.

40. Monteleone G, Kumberova A, Croft NM, McKenzie C, Steer HW, MacDonald TT: Blocking Smad7 restores TGF-beta1 signaling in chronic inflammatory bowel disease. J Clin Invest 2001, 108:601-609.

41. Schmidt C, Giese T, Ludwig B, Mueller-Molaian I, Marth T, Zeuzem S, Meuer SC, Stallmach A: Expression of interleukin-12-related cytokine transcripts in inflammatory bowel disease: elevated interleukin-23p19 and interleukin-27p28 in Crohn's disease but not in ulcerative colitis. Inflamm Bowel Dis 2005, 11:16-23.

42. Colonna M: Interleukin-22-producing natural killer cells and lymphoid tissue inducer-like cells in mucosal immunity. Immunity 2009, 31:15-23.

43. Park SG, Mathur R, Long M, Hosh N, Hao L, Hayden MS, Ghosh S: T regulatory cells maintain intestinal homeostasis by suppressing gammadelta T cells. Immunity 2010, 33:791-803.

44. Martin B, Hirota K, Cua DJ, Stockinger B, Veldhoen M: Interleukin-17producing gammadelta $T$ cells selectively expand in response to pathogen products and environmental signals. Immunity 2009, 31:321-330.

45. Spits H, Di Santo JP: The expanding family of innate lymphoid cells: regulators and effectors of immunity and tissue remodeling. Nat Immunol 2011, 12:21-27.

46. Geremia A, Arancibia-Carcamo CV, Fleming MP, Rust N, Singh B, Mortensen NJ, Travis SP, Powrie F: IL-23-responsive innate lymphoid cells are increased in inflammatory bowel disease. J Exp Med 2011, 208:1127-1133.

47. Buonocore S, Ahern PP, Uhlig HH, Littman DR, Maloy KJ, Powrie F: Innate lymphoid cells drive interleukin-23-dependent innate intestinal pathology. Nature 2010, 464:1371-1375.

48. Yang XO, Chang SH, Park H, Nurieva R, Shah B, Acero L, Wang YH, Schluns KS, Broaddus RR, Zhu Z, Dong C: Regulation of inflammatory responses by IL-17F. J Exp Med 2008, 205:1063-1075.

49. Strober W, Fuss IJ, Blumberg RS: The immunology of mucosal models of inflammation. Annu Rev Immunol 2002, 20:495-549.

50. Kinugasa T, Sakaguchi T, Gu X, Reinecker HC: Claudins regulate the intestinal barrier in response to immune mediators. Gastroenterology 2000, 118:1001-1011.

51. O'Connor W Jr, Kamanaka M, Booth CJ, Town T, Nakae S, Iwakura Y, Kolls JK, Flavell RA: A protective function for interleukin 17A in T cell-mediated intestinal inflammation. Nat Immunol 2009, 10:603-609.

52. Sugimoto K, Ogawa A, Mizoguchi E, Shimomura Y, Andoh A, Bhan AK, Blumberg RS, Xavier RJ, Mizoguchi A: IL-22 ameliorates intestinal inflammation in a mouse model of ulcerative colitis. J Clin Invest 2008 118:534-544.

53. Zenewicz LA, Yancopoulos GD, Valenzuela DM, Murphy AJ, Stevens $S$, Flavell RA: Innate and adaptive interleukin-22 protects mice from inflammatory bowel disease. Immunity 2008, 29:947-957.

54. Zhang Z, Zheng M, Bindas J, Schwarzenberger P, Kolls JK: Critical role of IL17 receptor signaling in acute TNBS-induced colitis. Inflamm Bowel Dis 2006, 12:382-388.

55. Moseley TA, Haudenschild DR, Rose L, Reddi AH: Interleukin-17 family and IL-17 receptors. Cytokine Growth Factor Rev 2003, 14:155-174

56. Leppkes M, Becker C, Hirth S, Wirtz S, Neufert C, Pouly S, Murphy AJ, Valenzuela DM, Yancopoulos GD, Becher B, Littman DR, Neurath MF: RORgamma-expressing Th17 cells induce murine chronic intestinal inflammation via redundant effects of IL-17A and IL-17F. Gastroenterology 2009, 136:257-267. 
57. Tajima M, Wakita D, Noguchi D, Chamoto K, Yue Z, Fugo K, Ishigame H, Iwakura Y, Kitamura H, Nishimura T: IL-6-dependent spontaneous proliferation is required for the induction of colitogenic IL-17-producing CD8+ T cells. J Exp Med 2008, 205:1019-1027.

58. Claesson MH, Bregenholt S, Bonhagen K, Thoma S, Moller P, Grusby MJ, Leithauser F, Nissen MH, Reimann J: Colitis-inducing potency of CD4+ T cells in immunodeficient, adoptive hosts depends on their state of activation, IL-12 responsiveness, and CD45RB surface phenotype. J Immunol 1999, 162:3702-3710.

59. Neurath MF, Weigmann B, Finotto S, Glickman J, Nieuwenhuis E, lijima $H$, Mizoguchi A, Mizoguchi E, Mudter J, Galle PR, Bhan A, Autschbach F, Sullivan BM, Szabo SJ, Glimcher LH, Blumberg RS: The transcription factor T-bet regulates mucosal T cell activation in experimental colitis and Crohn's disease. J Exp Med 2002, 195:1129-1143.

60. Fina D, Sarra M, Fantini MC, Rizzo A, Caruso R, Caprioli F, Stolfi C, Cardolini I, Dottori M, Boirivant M, Pallone F, Macdonald T, Monteleone G: Regulation of gut inflammation and th17 cell response by interleukin-21. Gastroenterology 2008, 134:1038-1048.

61. Peluso I, Fantini MC, Fina D, Caruso R, Boirivant M, MacDonald T, Pallone F, Monteleone G: IL-21 counteracts the regulatory $\mathrm{T}$ cell-mediated suppression of human CD4+ T lymphocytes. J Immunol 2007, 178:732-739

62. Monteleone G, Caruso R, Fina D, Peluso I, Gioia V, Stolfi C, Fantini MC, Caprioli F, Tersigni R, Alessandroni L, MacDonald TT, Pallone F: Control of matrix metalloproteinase production in human intestinal fibroblasts by interleukin 21. Gut 2006, 55:1774-1780.

63. Strengell M, Sareneva T, Foster D, Julkunen I, Matikainen S: IL-21 upregulates the expression of genes associated with innate immunity and Th1 response. J Immunol 2002, 169:3600-3605.

64. Strengell M, Matikainen S, Siren J, Lehtonen A, Foster D, Julkunen I, Sareneva T: IL-21 in synergy with IL-15 or IL-18 enhances IFN-gamma production in human NK and T cells. J Immunol 2003, 170:5464-5469.

65. Veldhoen M, Hirota K, Westendorf AM, Buer J, Dumoutier L, Renauld JC, Stockinger B: The aryl hydrocarbon receptor links TH17-cell-mediated autoimmunity to environmental toxins. Nature 2008, 453:106-109.

66. Quintana FJ, Basso AS, Iglesias AH, Korn T, Farez MF, Bettelli E, Caccamo M, Oukka $M$, Weiner HL: Control of $T(r e g)$ and $T(H) 17$ cell differentiation by the aryl hydrocarbon receptor. Nature 2008, 453:65-71.

67. Esser C, Rannug A, Stockinger B: The aryl hydrocarbon receptor in immunity. Trends Immunol 2009, 30:447-454.

68. Trifari S, Kaplan CD, Tran EH, Crellin NK, Spits H: Identification of a human helper $\mathrm{T}$ cell population that has abundant production of interleukin 22 and is distinct from $T(H)-17, T(H) 1$ and $T(H) 2$ cells. Nat Immunol 2009, 10:864-871.

69. Alam MS, Maekawa Y, Kitamura A, Tanigaki K, Yoshimoto T, Kishihara K, Yasutomo K: Notch signaling drives IL-22 secretion in CD4+ T cells by stimulating the aryl hydrocarbon receptor. Proc Natl Acad Sci USA 2010, 107:5943-5948.

70. Simonian $\mathrm{PL}$, Wehrmann F, Roark $\mathrm{CL}$, Born WK, O'Brien RL, Fontenot AP: gammadelta T cells protect against lung fibrosis via IL-22. J Exp Med 2010, 207:2239-2253.

71. Negishi T, Kato Y, Ooneda O, Mimura J, Takada T, Mochizuki H, Yamamoto M, Fujii-Kuriyama Y, Furusako S: Effects of aryl hydrocarbon receptor signaling on the modulation of $\mathrm{TH} 1 / \mathrm{TH} 2$ balance. J Immunol 2005, 175:7348-7356.

72. Rodriguez-Sosa M, Elizondo G, Lopez-Duran RM, Rivera I, Gonzalez FJ, Vega L: Over-production of IFN-gamma and IL-12 in AhR-null mice. FEBS Lett 2005, 579:6403-6410.

73. Kimura A, Naka T, Nohara K, Fujii-Kuriyama Y, Kishimoto T: Aryl hydrocarbon receptor regulates Stat1 activation and participates in the development of Th17 cells. Proc Natl Acad Sci USA 2008, 105:9721-9726.

74. Monteleone I, Rizzo A, Sarra M, Sica G, Sileri P, Biancone L, Macdonald TT, Pallone F, Monteleone G: Aryl Hydrocarbon Receptor-Induced Signals Upregulate IL-22 Production and Inhibit Inflammation in the Gastrointestinal Tract. Gastroenterology 2011, 141:237-248 e231.

75. Leonardi CL, Kimball AB, Papp KA, Yeilding N, Guzzo C, Wang Y, Li S, Dooley LT, Gordon KB: Efficacy and safety of ustekinumab, a human interleukin-12/23 monoclonal antibody, in patients with psoriasis: 76week results from a randomised, double-blind, placebo-controlled trial (PHOENIX 1). Lancet 2008, 371:1665-1674.
76. Mannon PJ, Fuss IJ, Mayer L, Elson CO, Sandborn WJ, Present D, Dolin B, Goodman N, Groden C, Hornung RL, Quezado M, Yang Z, Neurath MF, Salfeld J, Veldman GM, Schwertschlag U, Strober W, Anti-IL-12 Crohn's Disease Study Group: Anti-interleukin-12 antibody for active Crohn's disease. N Engl J Med 2004, 351:2069-2079.

77. Hueber W, Sands BE, Vandemeulebroecke M, Reinisch W, Higgins PDR, Wehkamp J, Feagan B, Yao M, Bertolino AP, Travis S: Inhibition of IL-17A by secukinumab is ineffective for Crohn's disease (CD). JCC 2011, 5:S10.

\section{Pre-publication history}

The pre-publication history for this paper can be accessed here: http://www.biomedcentral.com/1741-7015/9/122/prepub

doi:10.1186/1741-7015-9-122

Cite this article as: Monteleone et al: Th17-related cytokines: new players in the control of chronic intestinal inflammation. BMC Medicine 2011 9:122.

\section{Submit your next manuscript to BioMed Central and take full advantage of:}

- Convenient online submission

- Thorough peer review

- No space constraints or color figure charges

- Immediate publication on acceptance

- Inclusion in PubMed, CAS, Scopus and Google Scholar

- Research which is freely available for redistribution 